\title{
QUALITY ANALYSIS OF WATER NETWORK FAILURE
}

\section{JAKOŚCIOWA ANALIZA AWARII SIECI WODOCIĄGOWEJ}

\author{
Barbara Tchórzewska-Cieślak, Dawid Szpak, \\ Izabela Piegdoń, Anna Szlachta
}

Rzeszów University of Technology. Politechnika Rzeszowska

\begin{abstract}
The main objective of the study was to analyse and assess the failure rate of the water supply system of a provincial city located in south-eastern Poland. In the analysis the exploitation data provided by the water supply company were used. The received data include, among others, material structure, age of water supply network and failure log. The failure rate analysis of the water supply network was based on the failure rate index $\lambda$ [failure/(km.year)]. Based on the performed analysis, it was found that the water company should consider renovating or replacing steel pipes.
\end{abstract}

Keywords: collective water supply system, failure rate, water deficits

Streszczenie: Głównym celem pracy była analiza i ocena awaryjności sieci wodociagowej miasta wojewódzkiego zlokalizowanego w poludniowo-wschodniej Polsce. Do analizy wykorzystano dane eksploatacyjne udostępnione przez przedsiębiorstwo wodociagowe. Otrzymane dane obejmuja m.in. strukture materiatowa, wiekowa sieci wodociagowej oraz dziennik awarii. Analize awaryjności sieci wodociagowej przeprowadzono $w$ oparciu o wskaźnik intensywności uszkodzeń $\lambda$ [uszk./(km·rok)]. Na podstawie przeprowadzonej analizy stwierdzono, że przedsiębiorstwo powinno rozważyć renowację lub wymiane przewodów wykonanych ze stali.

Slowa kluczowe: system zbiorowego zaopatrzenia $w$ wodę, intensywność uszkodzeń, deficyty wody 
Quality analysis of water network failure

Jakościowa analiza awarii sieci wodociagowej

\section{QUALITY ANALYSIS OF WATER NETWORK FAILURE}

\section{Introduction}

According to the Act on Collective Water Supply and Collective Discharge of Wastewater, with later changes [15], water supply companies are required to ensure a continuous and reliable delivery of water to their customers, with priority given to the quality of supplied water. Water supply system is the most likely to fail element of the collective water supply system (CWSS). Its failure can cause water deficits in the certain areas, which is very burdensome for the inhabitants and may cause sanitary hazards. Therefore, measures should be taken to improve the reliability of the water supply system, among others, by analysing and evaluating the failure rate of the water supply network, including the causes and consequences of the failures, which will allow to select pipes to be upgraded or replaced. The consequences and extent of potential failures can be estimated based on computer hydraulic models of the water supply network [2].

Failure analysis of the water supply network has been the object of interest of scientists for several decades. In a monograph published in $2007 \mathrm{H}$. Hotloś analysed the influence of selected factors, among others the height of pressure, on the failure rate of water pipes [4]. M. Kwietniewski and J. Rak in a monograph [8] published in 2010, presented very extensive research on the reliability of water supply and sewage infrastructure in Poland and also indicated directions for further research in this field. The reliability of small group water supply systems was the subject of research of T. Bergel [1]. The important publications in this field include [3], [5-7], [11].

It was assumed that the failure rate is a measure of the reliability of water supply network. Reliability means the system's ability to perform its functions in accordance with the requirements in terms of functioning and safety. In relation to the CWSS it is to supply consumers with water in the right quality, quantity, under appropriate pressure and at an acceptable price, at any time [10], [13].

The failure rate of water pipes is influenced by a number of internal and external factors [4], [8], [14]:

- errors resulting from human activities, among others, design and implementation errors, mechanical damage of pipes,

- material causes, among others, material defects, corrosion,

- environmental causes, among others, unfavourable ground conditions, landslides,

- causes resulting from the operation of the water supply network, among others, too high pressure in the water supply network.

The main objective of the study was to analyse and assess the failure rate of the water supply system of a provincial city located in south-eastern Poland. In the analysis the exploitation data provided by the water supply company were used. 
The results of the work will complete the research conducted so far in this field and will provide valuable information for the exploiters of the CWSS.

\section{Research object}

The research covered the water supply network of the provincial city located in south-eastern Poland, which supplies about 200,000 inhabitants with water. The total length of the water supply network is $914.5 \mathrm{~km}$, including:

- the main network - $49.8 \mathrm{~km}$,

- the distribution network - $540.4 \mathrm{~km}$,

- the water supply connections $-324.3 \mathrm{~km}$.

The analysed water supply network is made of the following materials:

- grey cast iron $-104.0 \mathrm{~km}$,

- ductile iron $-8.0 \mathrm{~km}$,

- steel - $30.4 \mathrm{~km}$,

- asbestos cement $-3.7 \mathrm{~km}$,

- PVC-266.3 km,

- PE - $288.5 \mathrm{~km}$,

- other $-213.6 \mathrm{~km}$.

Main part of the water supply network are 5 main pipelines whose task is to distribute water through the supply area. The network is in $80 \%$ made in a ring system. The water supply network is shown in Figure 1.

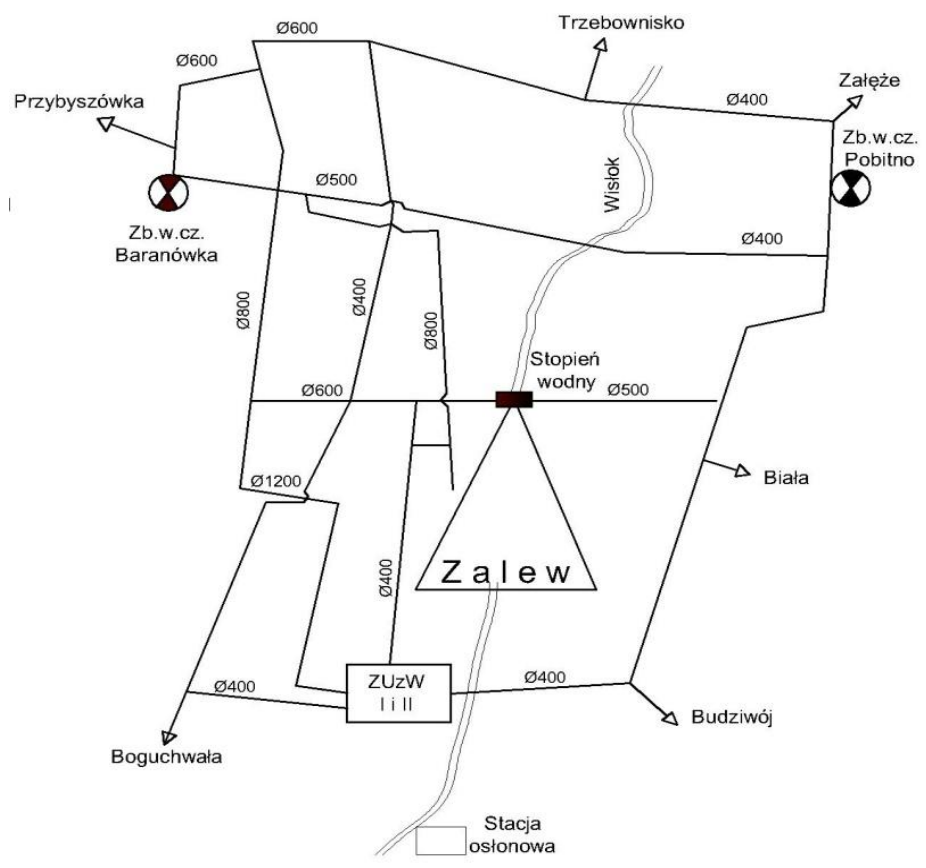

Fig. 1 A scheme of the analysed water supply network (based on [13]) 
Quality analysis of water network failure

Jakościowa analiza awarii sieci wodociagowej

\section{Research methodology}

Data for analysis were obtained from the water supply company managing the analysed water supply network. Documentation concerned a list of all failures in the years from 2013 to 2016 . The data on the material structure of the water supply network in 2015 were also obtained. The analysis was conducted for all types of pipes. According to the Act [15], water supply connections are not part of the water supply network, but, undoubtedly, they constitute an important element in the analysis of the reliability of water supply. Therefore, the failure analysis was carried out for the main line, the distribution pipes and the connections.

The failure log received from the water supply company contained such information as:

- date of failure notification,

- the street where the failure occurred,

- material and diameter of the damaged pipe,

- the cause of the failure,

- the time of repair and the time of interruption in water supply,

- date of failure removal,

- pipe type (main, distribution, connection).

The failure rate analysis of the water supply network was performed based on the value of the failure rate index, using the formula [3], [4], [8]:

where:

$$
\lambda=\frac{\mathrm{n}(\Delta \mathrm{t})}{\mathrm{L} \cdot \Delta \mathrm{t}}
$$

$\mathrm{n}(\Delta \mathrm{t})-$ the number of failures in the time interval $\Delta \mathrm{t}$,

$\mathrm{L} \quad-$ the length of examined pipes in the time interval $\Delta \mathrm{t}[\mathrm{km}]$,

$\Delta \mathrm{t} \quad-$ considered period of time [years].

The work determines the impact of the following factors on the failure rate of the water supply network:

- type and function of pipe,

- material of pipe,

- diameter of pipe.

The following causes of damage have been identified:

- rupture,

- unsealing,

- corrosion,

- break,

- mechanical damage. 
Data regarding the material structure of the analysed water supply network received from the waterworks include only 2015. Therefore, the percentage material distribution in that year was used to determine analogically the percentage share of a given material in the remaining years covered by the analysis.

The failure rate index was jointly determined for the main and distribution networks and separately for the connections. A division was also made considering the material from which the pipe is made.

\section{Results}

The percentage distribution of failures in water supply network is shown in Figure 2. The most frequent cause of failure of the water supply network is corrosion. About $50 \%$ of all failures was caused by corrosion pits. Corrosion products in water adversely affect the quality of water intended for consumption. Iron compounds may be released, consequently turbidity increases and the so-called red water is created [9]. Frequently the failure is caused by pipe unsealing (30\%) and pipe break (9\%).

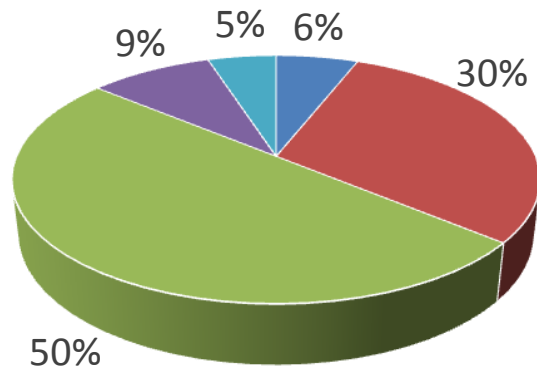

- rupture,

- unsealing,

corrosion,

- break,

- mechanical damage.

Fig. 2 Percentage distribution of failures in the water supply network

Information on failures together with the division into years, types of pipes, diameters and material is presented in table 1 . The most failures were recorded in water supply connections (about 46\%), slightly less in the distribution network (about $41 \%$ ).

On the basis of Table 1 it was found that a much larger number of failures occur in smaller diameters than in the larger ones. For the main network, failures in pipes with the diameter below $400 \mathrm{~mm}$ constitute about $80 \%$, while in the distribution networks about $57 \%$ of failures occurred in pipes with a diameter in the range of $25-50 \mathrm{~mm}$. Figure 3 shows the division of failures according to the material from which the pipe was made. 
Quality analysis of water network failure

Jakościowa analiza awarii sieci wodociagowej

Tab. 1 List of failures with the division into pipe diameters

\begin{tabular}{|c|c|c|c|c|c|c|c|c|c|c|}
\hline \multirow{3}{*}{ Year } & \multirow{2}{*}{\multicolumn{3}{|c|}{$\begin{array}{c}\text { Number of failures } \\
\text { in the main } \\
\text { network }\end{array}$}} & \multirow{2}{*}{\multicolumn{3}{|c|}{$\begin{array}{c}\text { Number of failures } \\
\text { in the distribution } \\
\text { network }\end{array}$}} & \multicolumn{4}{|c|}{$\begin{array}{l}\text { Number of failures in } \\
\text { the connections }\end{array}$} \\
\hline & & & & & & & \multicolumn{4}{|c|}{$\mathrm{d}[\mathrm{mm}]$} \\
\hline & $\begin{array}{l}\text { \& } \\
\text { + } \\
\text { ஓ }\end{array}$ & $\begin{array}{l}8 \\
8 \\
0 \\
8 \\
8 \\
+\end{array}$ & $\begin{array}{l}8 \\
8 \\
1 \\
8 \\
8\end{array}$ & $\begin{array}{l}8 \\
8 \\
8\end{array}$ & 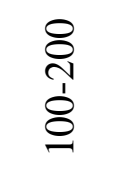 & 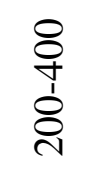 & $\begin{array}{l}i n \\
i \\
0\end{array}$ & 官 & $\begin{array}{l}n \\
\stackrel{n}{n} \\
i n\end{array}$ & $\frac{8}{\substack{n \\
r}}$ \\
\hline 2013 & 25 & 3 & 0 & 64 & 46 & 0 & 17 & 82 & 6 & 2 \\
\hline 2014 & 20 & 6 & 1 & 42 & 34 & 0 & 16 & 57 & 5 & 3 \\
\hline 2015 & 26 & 13 & 1 & 55 & 54 & 4 & 21 & 129 & 5 & 7 \\
\hline 2016 & 26 & 1 & 0 & 63 & 29 & 3 & 10 & 65 & 6 & 7 \\
\hline SUM & 97 & 23 & 2 & 224 & 163 & 7 & 64 & 333 & 22 & 19 \\
\hline percent & 79.51 & 18.85 & 1.64 & 56.85 & 41.37 & 1.78 & 14.61 & 76.03 & 5.02 & 4.34 \\
\hline
\end{tabular}

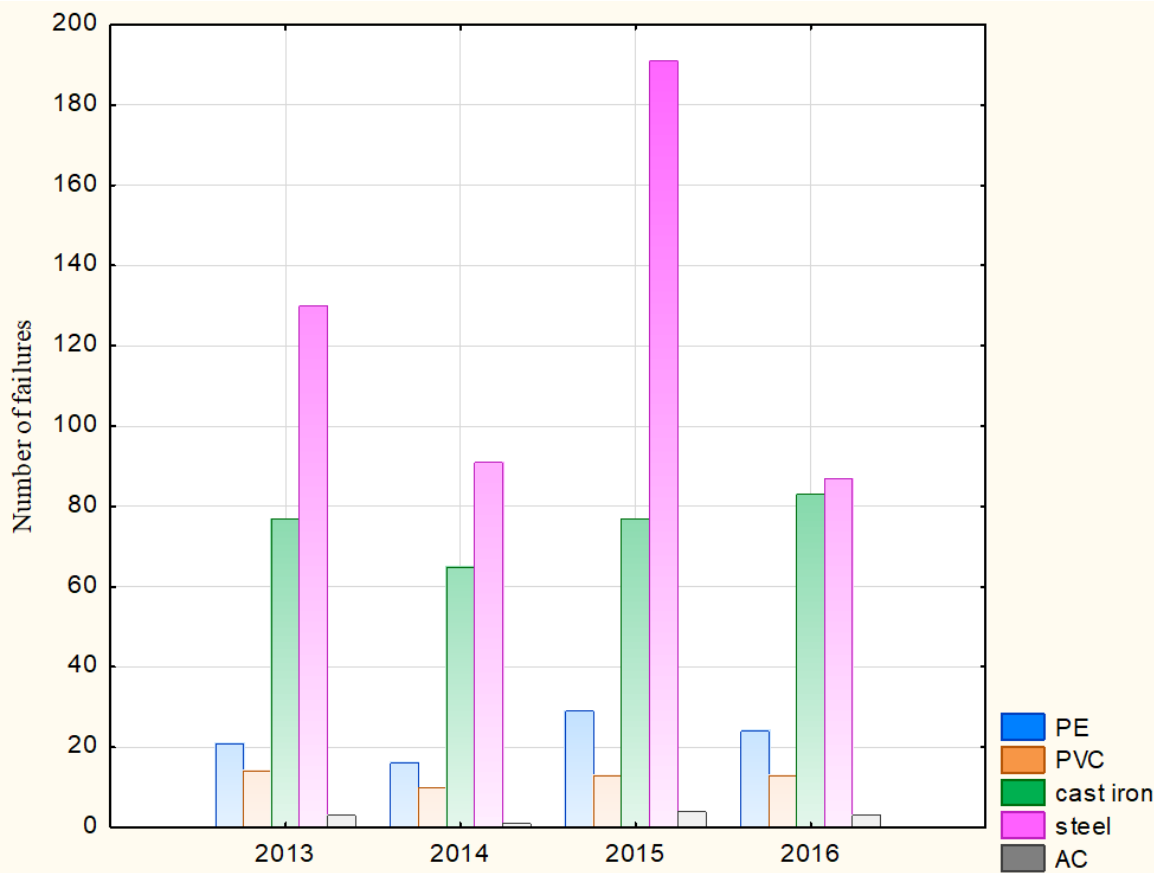

Fig. 3 Number of water supply system failures depending on the material of which the pipe is made 
Based on the information presented in Figure 3, it was found that over 50\% of failures occurred in pipes made of steel. A large number of failures is also characteristic for pipes made of cast iron (over 30\% of failures). The least number of failures was recorded in plastic and asbestos-cement pipes. Table 2 presents the failure rate index determined on the basis of formula (1) for the main network, distribution network and connections.

Tab. 2 The failure rate index (type of pipe)

\begin{tabular}{|c|c|c|c|c|c|}
\hline \multirow{3}{*}{ Type of water supply network } & \multicolumn{5}{|c|}{$\begin{array}{l}\text { The failure rate index } \\
\text { [failure/(km·year)] }\end{array}$} \\
\hline & \multicolumn{4}{|c|}{ Year } & \multirow{2}{*}{ Average } \\
\hline & 2013 & 2014 & 2015 & 2016 & \\
\hline The water supply connections & 0.799 & 0.596 & 1.204 & 0.641 & 0.810 \\
\hline $\begin{array}{l}\text { The main network }+ \\
\text { the distribution network }\end{array}$ & 0.267 & 0.192 & 0.272 & 0.236 & 0.242 \\
\hline
\end{tabular}

The analysis of the $\lambda$ index included cumulatively the main network and distribution network and separately the connections. Based on the conducted analysis, it was found that the connections are characterized by a much higher failure rate, which coincides with the research carried out in this respect [5], [7], [8], [12]. Due to the lack of legal conditions, the obtained results were referred to limit values of the failure rate indices for particular types of pipes, given, among others, in the works [4], [8]:

- the main network: $\lambda_{\mathrm{M}}=0,30 \mathrm{uszk} /(\mathrm{km} \cdot \mathrm{rok})$,

- the distribution pipes: $\lambda_{R}=0.50$ failure $/(\mathrm{km} \cdot$ year $)$,

- the household connections: $\lambda_{\mathrm{PD}}=1.00$ failure $/(\mathrm{km} \cdot$ year $)$.

In view of the above, the technical condition of the water pipes is assessed as good. Table 4 shows the value of the failure rate index in relation to the material from which the pipe was made. The method of determining the failure rate index for 2015 is presented in Table 3.

A detailed analysis of the failure rate of water pipes in the years 2013-2016 showed that the pipes made of plastics show the smallest failure rate value. For $\operatorname{PE} \lambda=0.079$ failure/(km.year) and for PVC $\lambda=0.067$ failure/(km.year).The pipes made of steel are characterized by the highest failure rate index $\lambda=4.167$ failure/(km·year). 
Quality analysis of water network failure

Jakościowa analiza awarii sieci wodociagowej

Tab. 3 Determination of the failure rate index for 2015

\begin{tabular}{|c|c|c|c|c|c|c|}
\hline \multirow{3}{*}{ Parameter } & \multirow{3}{*}{$\begin{array}{l}\text { Type of water } \\
\text { supply network }\end{array}$} & \multicolumn{5}{|c|}{2015} \\
\hline & & \multicolumn{5}{|c|}{ Material of pipe } \\
\hline & & $\mathrm{PE}$ & PVC & cast iron & steel & $\mathrm{AC}$ \\
\hline \multirow{2}{*}{$\begin{array}{l}\text { The length of } \\
\text { the water supply } \\
\text { network }[\mathrm{km}]\end{array}$} & $\begin{array}{c}\text { The main network } \\
+ \text { the distribution } \\
\text { network }\end{array}$ & 215.1 & 211.6 & 110.8 & 25.5 & 3.4 \\
\hline & $\begin{array}{l}\text { The water supply } \\
\text { connections }\end{array}$ & 73.4 & 54.7 & 1.2 & 4.9 & 0.3 \\
\hline \multirow{2}{*}{$\begin{array}{l}\text { Number of } \\
\text { failures }\end{array}$} & $\begin{array}{c}\text { The main network } \\
+ \text { the distribution } \\
\text { network }\end{array}$ & 16 & 13 & 76 & 45 & 4 \\
\hline & $\begin{array}{l}\text { The water supply } \\
\text { connections }\end{array}$ & 13 & 2 & 1 & 146 & 0 \\
\hline \multirow{2}{*}{$\begin{array}{l}\text { The failure rate } \\
\text { index } \\
\text { [fail./(km·year)] }\end{array}$} & $\begin{array}{c}\text { The main network } \\
+ \text { the distribution } \\
\text { network }\end{array}$ & 0.074 & 0.061 & 0.686 & 1.765 & 1.176 \\
\hline & $\begin{array}{c}\text { The water supply } \\
\text { connections }\end{array}$ & 0.177 & 0.037 & 0.833 & 29.796 & 0 \\
\hline \multirow{2}{*}{\multicolumn{2}{|c|}{$\begin{array}{l}\text { The total failure rate index } \\
\text { [failure/(km·year)] }\end{array}$}} & 0.101 & 0.056 & 0.688 & 6.283 & 1.081 \\
\hline & & & & 0.451 & & \\
\hline
\end{tabular}

Tab. 4 The failure rate index (material of pipe)

\begin{tabular}{|c|c|c|c|c|c|}
\hline \multirow{2}{*}{ Rok } & \multicolumn{5}{|c|}{$\begin{array}{c}\text { The failure rate index } \\
\text { [failure/(km·year) }]\end{array}$} \\
\cline { 2 - 6 } & \multicolumn{5}{|c|}{ Material of pipe } \\
\cline { 2 - 6 } & PE & PVC & cast iron & steel & AC \\
\hline 2013 & 0.075 & 0.085 & 0.712 & 4.409 & 0.838 \\
\hline 2014 & 0.057 & 0.050 & 0.597 & 3.065 & 0.277 \\
\hline 2015 & 0.101 & 0.056 & 0.688 & 6.283 & 1.081 \\
\hline 2016 & 0.085 & 0.076 & 0.756 & 2.912 & 0.826 \\
\hline The failure rate index \\
{$[$ failure/(km·year)] } & 0.079 & 0.067 & 0.688 & 4.167 & 0.756 \\
\cline { 2 - 6 } & & \multicolumn{5}{|c|}{0.352} \\
\hline
\end{tabular}




\section{Conclusions}

The most common cause of failure was corrosion. Failures caused by this process constitutes about $50 \%$ of all failures. About $30 \%$ of failures was caused by unsealing of pipe. The most failures were recorded in pipes made of steel and cast iron. Pipes made of these materials make about $15 \%$ of the network and failures that occurred in them make over $80 \%$ of all failures.

The assessment of the failure rate of the water supply network should be taken into account when deciding on the renovation or replacement of water supply pipes. It is necessary to modernize, in particular, those pipes which have a high failure rate index. Based on the performed analysis, it was found that the water company should consider renovating or replacing steel pipes with $\lambda=4.167$.

\section{References}

[1] Bergel T.: Awaryjność sieci wodociągowych małych wodociągów grupowych w Polsce. Gaz, woda i technika sanitarna. 12/2012, 536-538.

[2] Boryczko K., Tchorzewska-Cieslak B.: Analysis and assessment of the risk of lack of water supply using the EPANET program. Environmental Engineering IV - Pawłowski, Dudzińska \& Pawłowski (eds), Taylor \& Francis Group, London 2013, 63-68.

[3] Budziło B.: Niezawodność wybranych systemów zaopatrzenia $\mathrm{w}$ wodę w południowej Polsce. Wydawnictwo Politechniki Krakowskiej, Kraków, 2010.

[4] Hotloś H.: Ilościowa ocena wpływu wybranych czynników na parametry i koszty eksploatacyjne sieci wodociągowych. Oficyna Wydawnicza Politechniki Wrocławskiej, Wrocław, 2007.

[5] Iwanek M. Kowalska B., Kowalski D., Kwietniewski M., Miszta-Kruk K., Mikołajuk P.: Wpływ różnych czynników na awaryjność sieci wodociągowej w układzie przestrzennym - studium przypadku. Czasopismo Inżynierii Lądowej, Środowiska i Architektury JCEEA, t. XXXII, z. 62/2015, s. $167-183$.

[6] Kowalski D. Miszta-Kruk-K.: Failure of water supply networks in selected Polish towns based on the field reliability tests. Engineering Failure Analysis 35/2013, s. 736-742.

[7] Kwietniewski M.: Awaryjność infrastruktury wodociągowej i kanalizacyjnej w Polsce w świetle badań eksploatacyjnych. XXV Konferencja NaukowoTechniczna, Międzyzdroje 24-27 maja 2011.

[8] Kwietniewski M., Rak J.: Niezawodność infrastruktury wodociągowej i kanalizacyjnej w Polsce. Komitet Inżynierii Lądowej i Wodnej PAN, Warszawa, 2010.

[9] Nawrocki J., Świetlik J.: Analiza zjawiska korozji w sieciach wodociągowych, Czasopismo Ochrona środowiska, vol.33/4, s. 27-40.

[10] Piegdoń I., Tchórzewska-Cieślak B.: Wykorzystanie teorii zbiorów rozmytych w procesie zarządzania eksploatacją sieci wodociągowej. Journal of KONBiN 3(35)2015, 109-118. 
Quality analysis of water network failure

Jakościowa analiza awarii sieci wodociagowej

[11] Pietrucha-Urbanik K., Studziński A.: Wybrane aspekty kosztów oraz awaryjności przewodów przykładowego systemu wodociągowego. Rocznik Ochrona Środowiska. Tom 18, cz. 2, 2016, 616-627.

[12] Szpak D., Tchórzewska - Cieślak B.: Analiza awaryjności sieci wodociągowej $\mathrm{w}$ aspekcie bezpieczeństwa funkcjonowania infrastruktury krytycznej, CHEMIK 2014, 68, 10, 862-867.

[13] Tchórzewska-Cieślak B., Metody analizy i oceny ryzyka awarii podsystemu dystrybucji wody, Oficyna Wydawnicza Politechniki Rzeszowskiej, Rzeszów, 2011.

[14] Tchórzewska - Cieślak B., Szpak D.: Propozycja metody analizy i oceny bezpieczeństwa dostawy wody. Ochrona Środowiska 2015, Vol. 37, No. 3, pp. $43-47$.

[15] Ustawa $\mathrm{z}$ dnia 7 czerwca 2001 r. o zbiorowym zaopatrzeniu w wodę i zbiorowym odprowadzaniu ścieków (Dz.U. $2001 \mathrm{nr} 72$ poz. 747) z późniejszymi zmianami.

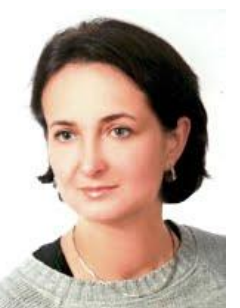

Prof. Barbara Tchórzewska-Cieślak, Ph.D.Eng. is working in the post of an associate professor in Rzeszow University of Technology, Faculty of Civil, Environmental Engineering and Architecture, Department of Water Supply and Sewage Systems. Research interests: water supply systems, reliability and safety of engineering systems, unconventional methods of risk analysis and assessment (Share 25\%).

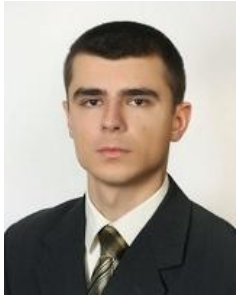

Dawid Szpak, Msc.Eng. is working in the post of an assistant in Rzeszow University of Technology, Faculty of Civil, Environmental Engineering and Architecture, Department of Water Supply and Sewage Systems. Research interests: reliability and security of water supply systems, incidental events in water supply systems (Share 25\%).

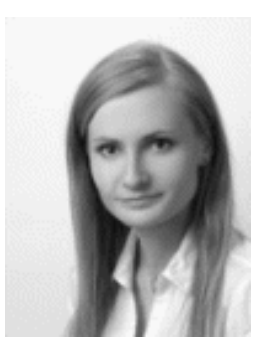

Izabela Piegdoń, Msc.Eng. is working in the post of an assistant in Rzeszow University of Technology, Faculty of Civil, Environmental Engineering and Architecture, Department of Water Supply and Sewage Systems. Research interests: reliability and security of water supply systems, IT techniques in management of water distribution systems (Share 25\%).

Anna Szlachta, Msc.Eng. is a graduate of the Rzeszow University of Technology. Field of study: environmental engineering, specialization: water supply and sewage systems (Share 25\%). 


\section{JAKOŚCIOWA ANALIZA AWARII SIECI WODOCIĄGOWEJ}

\section{Wstęp}

Zgodnie z ustawą o zbiorowym zaopatrzeniu w wodę i zbiorowym odprowadzaniu ścieków z późniejszymi zmianami [15], przedsiębiorstwa wodociągowe mają obowiązek zapewnić ciągłą i niezawodną dostawę wody do odbiorców, przy czym priorytet ma zapewnienie wymaganej jakości dostarczanej wody. Sieć wodociągowa jest najbardziej awaryjnym elementem systemu zbiorowego zaopatrzenia w wodę (SZZW). Jej awaryjność może powodować występowanie deficytów wody na określonych obszarach, co jest bardzo uciążliwe dla mieszkańców, oraz może być powodem zagrożenia sanitarnego. W związku z tym należy podejmować działania mające na celu podniesienie niezawodności sieci wodociągowej, m.in. poprzez analizę i ocenę awaryjności sieci wodociągowej obejmującą przyczyny i skutki występujących awarii, co pozwoli na wytypowanie przewodów do modernizacji lub wymiany. Skutki oraz zasięg potencjalnych awarii moga zostać oszacowane w oparciu o komputerowe modele hydrauliczne sieci wodociągowej [2].

Badania dotyczące awaryjności sieci wodociągowych w Polsce są prowadzone od kilkudziesięciu lat. W monografii wydanej w 2007 roku H. Hotloś przeanalizowała wpływ wybranych czynników, m.in. wysokości ciśnienia na awaryjność przewodów wodociągowych [4]. M. Kwietniewski oraz J. Rak w monografii [8] wydanej w 2010 roku przedstawili bardzo szerokie badania na temat niezawodności infrastruktury wodociągowej i kanalizacyjnej w Polsce, a także wskazali kierunki dalszych badań $w$ tym zakresie. Niezawodnością sieci wodociągowych małych wodociągów grupowych zajmował się T. Bergel [1]. Do istotnych publikacji w tym zakresie należy zaliczyć także prace [3], [5-7], [11].

Przyjęto, że awaryjność jest miarą niezawodności sieci wodociągowej. Przez niezawodność rozumie się zdolność systemu do realizowania przynależnych mu funkcji, zgodnie z wymaganiami pod względem funkcjonowania i bezpieczeństwa. W odniesieniu do SZZW, jest to dostarczenie wody do konsumentów w odpowiedniej jakości, ilości, pod odpowiednim ciśnieniem oraz w akceptowalnej cenie w dowolnej chwili czasu [10], [13].

$\mathrm{Na}$ awaryjność przewodów wodociagowych wpływa szereg czynników wewnętrzynych oraz zewnętrznych [4], [8], [14]:

- błędy wynikające $\mathrm{z}$ działań człowieka, m.in. błędy projektowe oraz wykonawcze, uszkodzenie mechaniczne przewodów,

- przyczyny materiałowe, m.in. wady materiałowe, korozja,

- przyczyny środowiskowe, m.in. niekorzystne warunki gruntowe, osuwiska,

- przyczyny wynikające z funkcjonowania sieci wodociągowej, m.in. zbyt duże ciśnienie w sieci wodociągowej.

Głównym celem pracy jest analiza i ocena awaryjności sieci wodociągowej miasta wojewódzkiego zlokalizowanego w południowo-wschodniej Polsce. Do analizy wykorzystano dane eksploatacyjne pozyskane od przedsiębiorstwa wodociągowego. Wyniki pracy uzupełnią dotychczas prowadzone badania w tym zakresie oraz będą stanowiły cenną informację dla eksploatatorów SZZW. 
Quality analysis of water network failure

Jakościowa analiza awarii sieci wodociagowej

\section{Przedmiot badań}

Badaniami objęto sieć wodociągową miasta wojewódzkiego zlokalizowanego w południowo-wschodniej Polsce, która zaopatruje w wodę około 200000 mieszkańców. Łączna długość sieci wodociągowej wynosi 914,5 km, w tym:

- sieć magistralna - 49,8 km,

- sieć rozdzielcza - 540,4 km,

- przyłącza wodociągowe - 324,3 km.

Analizowana sieć wodociągowa wykonana jest z następujących materiałów:

- żeliwo szare - 104,0 km,

- żeliwo sferoidalne $-8,0 \mathrm{~km}$,

- stal - 30,4 km,

- azbestocement $-3,7 \mathrm{~km}$,

- PVC-266,3 km,

- PE - 288,5 km,

- inne $-213,6 \mathrm{~km}$.

Szkielet sieci wodociągowej stanowi 5 rurociągów magistralnych, których zadaniem jest rozprowadzenie wody po obszarze zasilania. Sieć w $80 \%$ wykonana jest w układzie pierścieniowym. Szkielet sieci wodociągowej przedstawiono na rysunku 1.

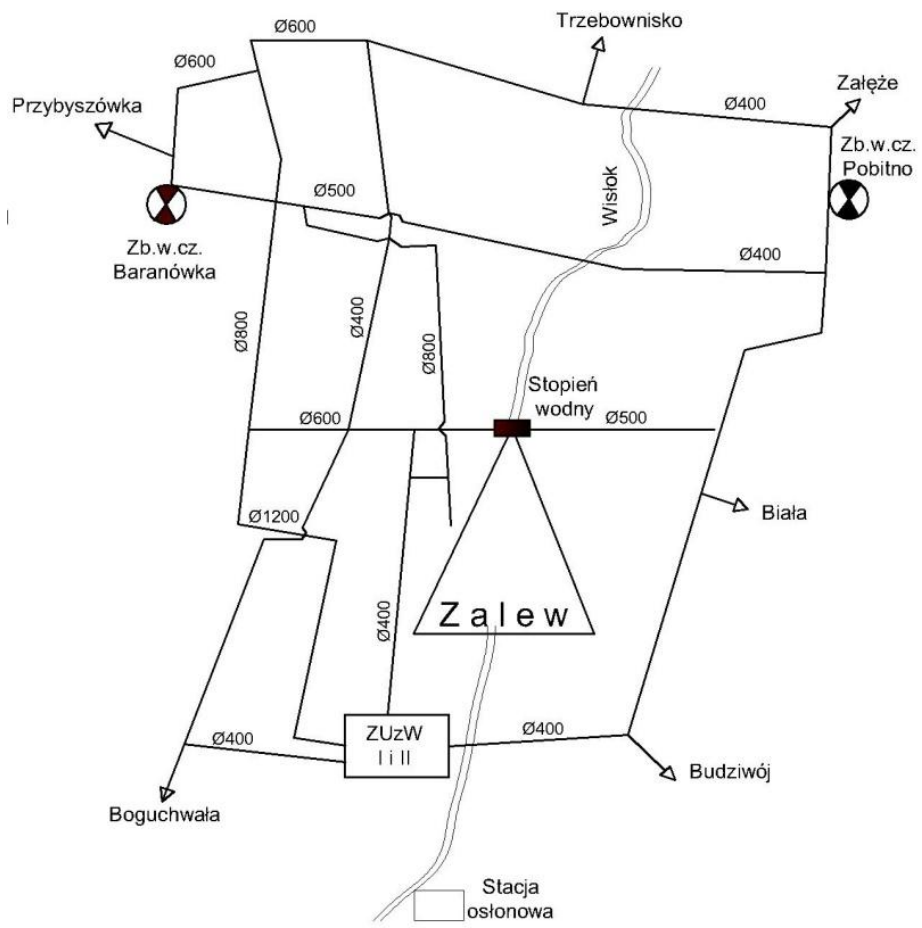

Rys. 1 Szkielet analizowanej sieci wodociagowej (na podstawie [13]) 


\section{Metodyka badań}

Dane do analizy pozyskano od przedsiębiorstwa wodociągowego zarządzającego analizowaną siecią wodociągową. Dokumentacja ta dotyczyła spisu wszystkich awarii w okresie od 2013 do 2016 roku. Pozyskano również dane dotyczące struktury materiałowej sieci wodociągowej w 2015 r. Analizę przeprowadzono dla wszystkich rodzajów przewodów. Według Ustawy [15], przyłącza wodociągowe nie stanowią elementu sieci wodociągowej, jednak niezaprzeczalnie stanowią one istotny element $\mathrm{w}$ analizie niezawodności dostawy wody. Analizę awaryjności przeprowadzono zatem dla magistrali, przewodów rozdzielczych oraz przyłączy.

Otrzymany od przedsiębiorstwa wodociągowego dziennik awarii zawierał takie informacje jak:

- data zgłoszenia awarii,

- ulica na której doszło do awarii,

- materiał i średnica uszkodzonego przewodu,

- przyczyna awarii,

- czas naprawy oraz czas wstrzymania dostawy wody,

- data usunięcia awarii,

- rodzaj przewodu (magistrala, przewód rozdzielczy, przyłącze).

Analizę stanu technicznego sieci wodociągowej przeprowadzono w oparciu o wskaźnik intensywności uszkodzeń wg wzoru [3], [4], [8]:

$$
\lambda=\frac{n(\Delta t)}{L \cdot \Delta t}, u s z k / k m \cdot a
$$

gdzie:

$\mathrm{n}(\Delta \mathrm{t})-$ liczba uszkodzeń w przedziale czasu $\Delta \mathrm{t}$,

$\mathrm{L} \quad-$ długość badanych przewodów w przedziale czasu $\Delta \mathrm{t}, \mathrm{km}$,

$\Delta \mathrm{t} \quad-$ rozpatrywany przedział czasu, lata.

W pracy określono wpływ następujących czynników na awaryjność sieci wodociągowej:

- rodzaj i funkcja przewodu,

- materiał przewodu,

- średnica przewodu.

Zidentyfikowano następujące przyczyny uszkodzeń:

- pękniecie,

- rozszczelnienie,

- korozja,

- złamanie,

- uszkodzenie mechaniczne.

Dane odnośnie struktury materiałowej sieci wodociągowej poddanej analizie otrzymane od Przedsiębiorstwa uwzględniają jedynie 2015 rok. 
Quality analysis of water network failure

Jakościowa analiza awarii sieci wodociagowej

W związku z tym posłużono się procentowym rozkładem materiałowym tego roku do analogicznego wyznaczenia udziału procentowanego danego materiału w latach pozostałych objętych analizą. Wskaźnik intensywności uszkodzeń wyznaczono wspólnie dla sieci magistralnej i rozdzielczej oraz oddzielnie dla przyłączy. Dokonano również podziału ze względu na materiał $\mathrm{z}$ jakiego wykonany jest przewód.

\section{Wyniki badań}

Procentowy rozkład uszkodzeń w sieci wodociągowej przedstawiono na rysunku 2. Najczęstszą przyczyną awarii sieci wodociągowej jest korozja. Około 50\% wszystkich uszkodzeń było spowodowanych przez wżery korozyjne. Produkty korozji znajdujące się w wodzie wpływają niekorzystnie na jakość wody przeznaczonej do spożycia. Może nastąpić uwalnianie związków żelaza, a co za tym idzie zwiększenie mętności oraz powstawanie tzw. czerwonej wody [9]. Do częstych przyczyny awarii należy także rozszczelnienie przewodu (30\%) oraz złamanie przewodu $(9 \%)$.

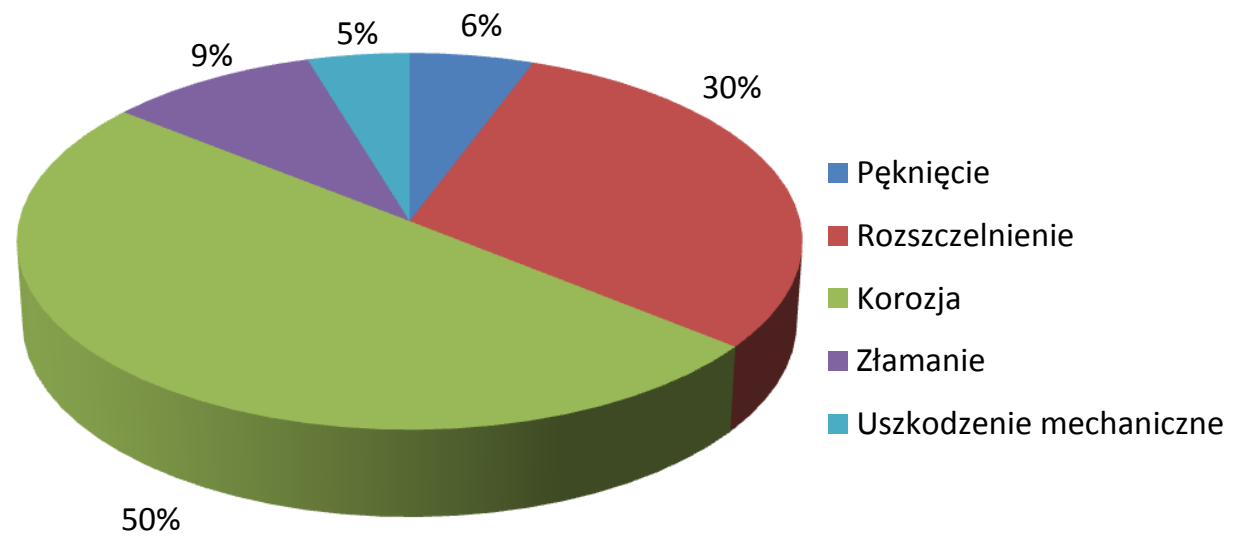

Rys. 2 Procentowy rozkład uszkodzeń w sieci wodociagowej

Informacje o uszkodzeniach wraz $\mathrm{z}$ podziałem na lata, rodzaje przewodów, średnice oraz materiał zestawiono $\mathrm{w}$ tabeli 1 . Najwięcej awarii odnotowano na przyłączach wodociągowych (około $46 \%$ ), nieznacznie mniej na sieci rozdzielczej (około 41\%).

Na podstawie tabeli 1 stwierdzono, że znacznie większa liczba awarii występuje na mniejszych średnicach, aniżeli na większych. W przypadku magistral około $80 \%$ stanowią awarie przewodów poniżej $400 \mathrm{~mm}$, natomiast w sieciach rozdzielczych około $57 \%$ awarii wystąpiło na przewodach o średnicy do $100 \mathrm{~mm}$. Na przyłączach około $76 \%$ awarii dotyczyło przewodów o średnicy w zakresie 25-50 mm. 
Izabela Piegdoń, Barbara Tchórzewska-Cieślak, Dawid Szpak, Anna Szlachta

Tab. 1 Zestawienie awarii z podziatem na średnice przewodów

\begin{tabular}{|c|c|c|c|c|c|c|c|c|c|c|}
\hline \multirow{3}{*}{ Rok } & \multirow{2}{*}{\multicolumn{3}{|c|}{$\begin{array}{c}\text { Liczba awarii sieci } \\
\text { magistralnej }\end{array}$}} & \multirow{2}{*}{\multicolumn{3}{|c|}{$\begin{array}{c}\begin{array}{c}\text { Liczba awarii sieci } \\
\text { rozdzielczej }\end{array} \\
\mathrm{d}[\mathrm{mm}]\end{array}$}} & \multicolumn{4}{|c|}{ Liczba awarii przyłączy } \\
\hline & & & & & & & & $\mathrm{d}[\mathrm{m}$ & & \\
\hline & $\begin{array}{l}8 \\
\stackrel{8}{+} \\
\text { 1 } \\
\text { } \\
\text { d }\end{array}$ & \begin{tabular}{l}
8 \\
8 \\
1 \\
8 \\
\multirow{+}{1}{}
\end{tabular} & $\begin{array}{l}8 \\
8 \\
\infty \\
8 \\
8 \\
0\end{array}$ & $\begin{array}{l}8 \\
8 \\
8 \\
\end{array}$ & $\begin{array}{l}8 \\
\text { ำ } \\
\text { ᄋ̊ }\end{array}$ & $\begin{array}{l}\stackrel{8}{8} \\
\text { +1 } \\
\text { } \\
\text { ¿ }\end{array}$ & \begin{tabular}{l}
$n$ \\
\multirow{2}{0}{} \\
0
\end{tabular} & $\begin{array}{l}\stackrel{n}{n} \\
\stackrel{1}{n}\end{array}$ & $\begin{array}{l}n \\
\frac{1}{1} \\
n\end{array}$ & $\frac{8}{2}$ \\
\hline 2013 & 25 & 3 & 0 & 64 & 46 & 0 & 17 & 82 & 6 & 2 \\
\hline 2014 & 20 & 6 & 1 & 42 & 34 & 0 & 16 & 57 & 5 & 3 \\
\hline 2015 & 26 & 13 & 1 & 55 & 54 & 4 & 21 & 129 & 5 & 7 \\
\hline 2016 & 26 & 1 & 0 & 63 & 29 & 3 & 10 & 65 & 6 & 7 \\
\hline SUMA & 97 & 23 & 2 & 224 & 163 & 7 & 64 & 333 & 22 & 19 \\
\hline $\begin{array}{c}\text { Udział } \\
\%\end{array}$ & 79,51 & 18,85 & 1,64 & 56,85 & 41,37 & 1,78 & 14,61 & 76,03 & 5,02 & 4,34 \\
\hline
\end{tabular}

Na rysunku 3 przedstawiono podział awarii ze względu na materiał z jakiego wykonano przewód.

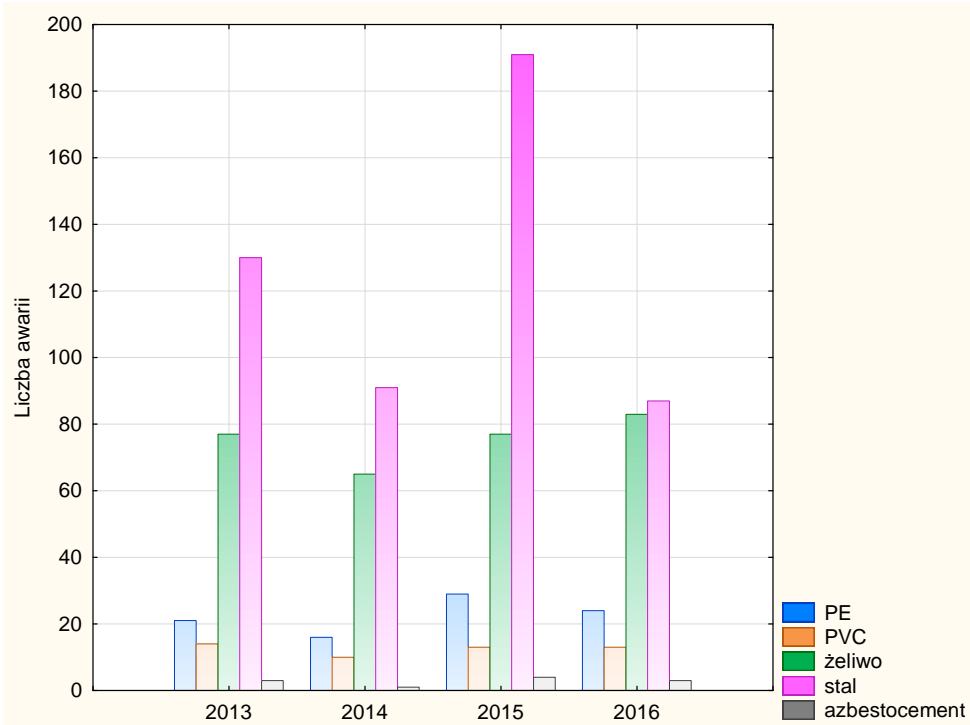

Rys. 3 Liczba awarii sieci wodociagowej w zależności od materiału z jakiego wykonany jest przewód 
Quality analysis of water network failure

Jakościowa analiza awarii sieci wodociagowej

$\mathrm{Na}$ podstawie informacji przedstawionych na rysunku 3 stwierdzono, że ponad $50 \%$ awarii wystąpiło na przewodach wykonanych ze stali. Dużą liczbą uszkodzeń charakteryzują się także przewody wykonane z żeliwa (ponad 30\% awarii). Najmniej awarii odnotowano na przewodach wykonanych z tworzyw sztucznych oraz azbestocementu. W tabeli 2 przedstawiono wskaźnik intensywności uszkodzeń wyznaczony na podstawie wzoru (1) dla sieci magistralnej, sieci rozdzielczej oraz przyłączy.

Tab. 2 Wskaźnik intensywności uszkodzeń (rodzaj przewodu)

\begin{tabular}{|c|c|c|c|c|c|}
\hline \multirow{2}{*}{ Typ przewodu } & \multicolumn{5}{|c|}{ Wskaźnik intensywności uszkodzeń } \\
[uszk./(km·rok)]
\end{tabular}

Analiza wskaźnika $\lambda$ obejmowała sumarycznie sieć magistralną i rozdzielczą oraz oddzielnie przyłącza. Na podstawie przeprowadzonej analizy stwierdzono, że przyłącza charakteryzują się znacznie wyższą awaryjnością, co pokrywa się $\mathrm{z}$ badaniami prowadzonymi w tym zakresie [5], [7], [8], [12]. Ze względu na fakt, iż nie ma obecnie uwarunkowań prawnych dotyczących wartości granicznych wskaźnika intensywności uszkodzeń, w pracy oparto się na danych literaturowych [4], [8]:

- przewody magistralne: $\lambda_{\mathrm{M}}=0,30 \mathrm{uszk} /(\mathrm{km} \cdot \mathrm{rok})$,

- przewody rozdzielcze: $\lambda_{\mathrm{R}}=0,50 \mathrm{uszk} /(\mathrm{km} \cdot \mathrm{rok})$,

- podłączenia domowe: $\lambda_{\mathrm{PD}}=1,00 \mathrm{uszk} /(\mathrm{km} \cdot \mathrm{rok})$.

Wobec powyższego stan techniczny przewodów wodociągowych ocenia się jako dobry. Tabela 4 przedstawia wartość wskaźnika intensywności uszkodzeń w odniesieniu do materiału z jakiego wykonano przewód. Sposób wyznaczenia wskaźnika intensywności uszkodzeń dla 2015 roku przedstawiono w tabeli 3.

Szczegółowa analiza intensywności uszkodzeń przewodów wodociągowych w latach 2013-2016 wykazała, że przewody wykonane z tworzyw sztucznych wykazują najmniejszą wartość intensywności uszkodzeń. W przypadku PE $\lambda=0,079$ uszk./(km·rok), natomiast dla PVC $\lambda=0,067$ uszk./(km·rok). Przewody wykonane ze stali charakteryzują się największym wskaźnikiem intensywności uszkodzeń $\lambda=4,167$ uszk./(km·rok). 
Izabela Piegdoń, Barbara Tchórzewska-Cieślak, Dawid Szpak, Anna Szlachta

Tab. 3 Wyznaczenie wskaźnika intensywności uszkodzeń dla 2015roku

\begin{tabular}{|c|c|c|c|c|c|c|}
\hline \multirow{3}{*}{ Parametr } & \multirow{3}{*}{ Rodzaj sieci } & \multicolumn{5}{|c|}{ Rok 2015} \\
\hline & & \multicolumn{5}{|c|}{ Materiał przewodu } \\
\hline & & $\mathrm{PE}$ & PVC & żeliwo & stal & $\mathrm{AC}$ \\
\hline \multirow{2}{*}{$\begin{array}{l}\text { Długość sieci } \\
{[\mathrm{km}]}\end{array}$} & $\begin{array}{l}\text { Sieć magistralna + } \\
\text { rozdzielcza }\end{array}$ & 215,1 & 211,6 & 110,8 & 25,5 & 3,4 \\
\hline & Przyłącza & 73,4 & 54,7 & 1,2 & 4,9 & 0,3 \\
\hline \multirow{2}{*}{ Liczba awarii } & $\begin{array}{c}\text { Sieć magistralna }+ \\
\text { rozdzielcza }\end{array}$ & 16 & 13 & 76 & 45 & 4 \\
\hline & Przyłącza & 13 & 2 & 1 & 146 & 0 \\
\hline \multirow{2}{*}{$\begin{array}{c}\text { Wskaźnik } \\
\text { intensywności } \\
\text { uszkodzeń } \\
\text { [uszk./(km·rok)] }\end{array}$} & $\begin{array}{c}\text { Sieć magistralna }+ \\
\text { rozdzielcza }\end{array}$ & 0,074 & 0,061 & 0,686 & 1,765 & 1,176 \\
\hline & Przyłącza & 0,177 & 0,037 & 0,833 & 29,796 & 0 \\
\hline \multirow{2}{*}{\multicolumn{2}{|c|}{$\begin{array}{c}\text { Całkowity wskaźnik intensywności } \\
\text { uszkodzeń [uszk./km·rok] }\end{array}$}} & 0,101 & 0,056 & 0,688 & 6,283 & 1,081 \\
\hline & & \multicolumn{5}{|c|}{0,451} \\
\hline
\end{tabular}

Tab. 4 Wskaźnik intensywności uszkodzeń (materiał przewodu)

\begin{tabular}{|c|c|c|c|c|c|}
\hline \multirow{3}{*}{ Rok } & \multicolumn{5}{|c|}{ Wskaźnik intensywności uszkodzeń [uszk./(km·rok)] } \\
\hline & \multicolumn{5}{|c|}{ Materiał przewodu } \\
\hline & $\mathrm{PE}$ & PVC & żeliwo & stal & azbestocement \\
\hline 2013 & 0,075 & 0,085 & 0,712 & 4,409 & 0,838 \\
\hline 2014 & 0,057 & 0,050 & 0,597 & 3,065 & 0,277 \\
\hline 2015 & 0,101 & 0,056 & 0,688 & 6,283 & 1,081 \\
\hline 2016 & 0,085 & 0,076 & 0,756 & 2,912 & 0,826 \\
\hline \multirow{2}{*}{$\begin{array}{l}\text { Wskaźnik intensywności } \\
\text { uszkodzeń [uszk./km·rok] }\end{array}$} & 0,079 & 0,067 & 0,688 & 4,167 & 0,756 \\
\hline & \multicolumn{5}{|c|}{0,352} \\
\hline
\end{tabular}


Quality analysis of water network failure

Jakościowa analiza awarii sieci wodociagowej

\section{Wnioski}

Najczęstszą przyczyną awarii była korozja. Uszkodzenia spowodowane tym procesem stanowią około $50 \%$ wszystkich uszkodzeń. Około $30 \%$ awarii spowodowanych było rozszczelnieniem przewodu. Najwięcej awarii odnotowano na przewodach wykonanych ze stali oraz żeliwa. Przewody zbudowane $\mathrm{z}$ tych materiałów stanowią około $15 \%$ sieci, a awarie które na nich wystąpiły, ponad $80 \%$ wszystkich awarii.

Ocena awaryjności sieci wodociągowej powinna zostać uwzględniona przy podejmowaniu decyzji dotyczących renowacji lub wymiany przewodów wodociągowych. Konieczna jest modernizacja przede wszystkim tych przewodów, które charakteryzują się wysokim wskaźnikiem intensywności uszkodzeń. Na podstawie przeprowadzonej analizy stwierdzono, że przedsiębiorstwo powinno rozważyć renowację lub wymianę przewodów wykonanych ze stali $\lambda=4,167$ uszk./(km·rok).

\section{Literatura}

[1] Bergel T.: Awaryjność sieci wodociągowych małych wodociągów grupowych w Polsce. Gaz, woda i technika sanitarna. 12/2012, 536-538.

[2] Boryczko K., Tchorzewska-Cieslak B.: Analysis and assessment of the risk of lack of water supply using the EPANET program. Environmental Engineering IV - Pawłowski, Dudzińska \& Pawłowski (eds), Taylor \& Francis Group, London 2013, 63-68.

[3] Budziło B.: Niezawodność wybranych systemów zaopatrzenia w wodę w południowej Polsce. Wydawnictwo Politechniki Krakowskiej, Kraków, 2010.

[4] Hotloś H.: Ilościowa ocena wpływu wybranych czynników na parametry i koszty eksploatacyjne sieci wodociągowych. Oficyna Wydawnicza Politechniki Wrocławskiej, Wrocław, 2007.

[5] Iwanek M. Kowalska B., Kowalski D., Kwietniewski M., Miszta-Kruk K., Mikołajuk P.: Wpływ różnych czynników na awaryjność sieci wodociągowej w układzie przestrzennym - studium przypadku. Czasopismo Inżynierii Lądowej, Środowiska i Architektury JCEEA, t. XXXII, z. 62/2015, s. 167-183.

[6] Kowalski D. Miszta-Kruk-K.: Failure of water supply networks in selected Polish towns based on the field reliability tests. Engineering Failure Analysis 35/2013, s. 736-742.

[7] Kwietniewski M.: Awaryjność infrastruktury wodociągowej i kanalizacyjnej w Polsce w świetle badań eksploatacyjnych. XXV Konferencja NaukowoTechniczna, Międzyzdroje 24-27 maja 2011.

[8] Kwietniewski M., Rak J.: Niezawodność infrastruktury wodociągowej i kanalizacyjnej w Polsce. Komitet Inżynierii Lądowej i Wodnej PAN, Warszawa, 2010.

[9] Nawrocki J., Świetlik J.: Analiza zjawiska korozji w sieciach wodociągowych, Czasopismo Ochrona środowiska, vol.33/4, s. 27-40.

[10] Piegdoń I., Tchórzewska-Cieślak B.: Wykorzystanie teorii zbiorów rozmytych w procesie zarządzania eksploatacją sieci wodociągowej. Journal of KONBiN 3(35)2015, 109-118. 
[11] Pietrucha-Urbanik K., Studziński A.: Wybrane aspekty kosztów oraz awaryjności przewodów przykładowego systemu wodociągowego. Rocznik Ochrona Środowiska. Tom 18, cz. 2, 2016, 616-627.

[12] Szpak D., Tchórzewska - Cieślak B.: Analiza awaryjności sieci wodociągowej $\mathrm{w}$ aspekcie bezpieczeństwa funkcjonowania infrastruktury krytycznej, CHEMIK 2014, 68, 10, 862-867.

[13] Tchórzewska-Cieślak B., Metody analizy i oceny ryzyka awarii podsystemu dystrybucji wody, Oficyna Wydawnicza Politechniki Rzeszowskiej, Rzeszów, 2011.

[14] Tchórzewska - Cieślak B., Szpak D.: Propozycja metody analizy i oceny bezpieczeństwa dostawy wody. Ochrona Środowiska 2015, Vol. 37, No. 3, pp. $43-47$.

[15] Ustawa $\mathrm{z}$ dnia 7 czerwca $2001 \mathrm{r}$. o zbiorowym zaopatrzeniu w wodę i zbiorowym odprowadzaniu ścieków (Dz.U. $2001 \mathrm{nr} 72$ poz. 747) z późniejszymi zmianami.

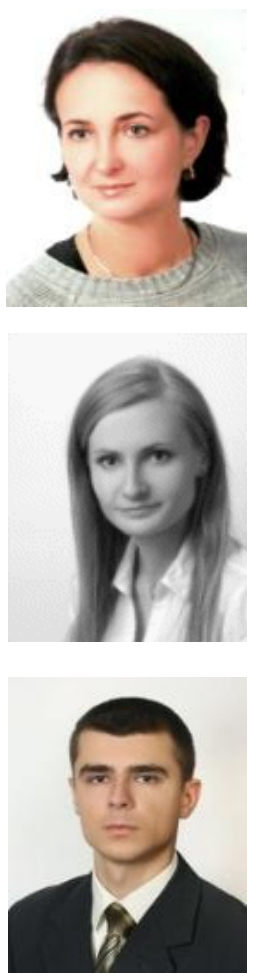

Dr hab. inż. Barbara Tchórzewska-Cieślak, prof. PRz pracuje na stanowisku profesora nadzwyczajnego $w$ Politechnice Rzeszowskiej w Katedrze Zaopatrzenia w Wode i Odprowadzania Ścieków.Zainteresowania naukowe - eksploatacja systemów zbiorowego zaopatrzenia w wodę, niezawodność i bezpieczeństwo systemów inżynierskich, niekonwencjonalne metody analizy i oceny ryzyka (Udziat 25\%).

Mgr inż. Izabela Piegdoń pracuje na stanowisku asystenta $w$ Politechnice Rzeszowskiej w Katedrze Zaopatrzenia w Wode $i$ Odprowadzania Ścieków. Zainteresowania naukowe niezawodność i bezpieczeństwo systemów inżynierskich, techniki informatyczne w zarzadzaniu systemami dystrybucji wody (Udziat $25 \%)$.

Mgr inz. Dawid Szpak pracuje na stanowisku asystenta w Zaktadzie Zaopatrzenia w Wodę i Odprowadzania Ścieków Politechniki Rzeszowskiej. Zainteresowania naukowe: niezawodność $i$ bezpieczeństwo systemów zaopatrzenia $w$ wodę, $z$ darzenia incydentalne $w$ systemach zaopatrzenia $w$ wode (Udziat 25\%).

Mgr inż. Anna Szlachta. W 2017 roku obronita tytut magistra inżynieria na Wydziale Budownictwa, Inżynierii Środowiska i Architektury, na kierunku Inżynieria Środowiska, specjalizacja zaopatrzenie $w$ wode $i$ odprowadzanie ścieków (Udziat 25\%). 